\title{
AN INSILCO STUDY OF 1,1-DIFLUORO-2-METHOXYPROPANE REACTION MECHANISM WITH THE BROMINE MONOXIDE (BrO) RADICAL
}

\author{
M. A. RUFAI ${ }^{1,}{ }^{*}$, U. ADAMU ${ }^{1}$, S. GIDEON ${ }^{1}$ and S. UBA ${ }^{1}$ \\ ${ }^{1}$ Ahmadu Bello University, Department of Chemistry, Zaria, Kaduna State, Nigeria \\ ${ }^{*}$ Corresponding author. Ahmadu Bello University, Department of Chemistry, Zaria, Kaduna State, Nigeria, Phone: +2347033748067 \\ e-mail addressl: marufai2424@gmail.com (M. A. Rufai).
}

\begin{tabular}{l} 
A R T I C L E I N F O \\
\hline Article history: \\
Received 2018-06-05 \\
Accepted 2018-08-27 \\
Available online 2019-03-08 \\
pa la bra s clave \\
l,1-difluoro-2- \\
metoxipropano \\
DFT \\
CFCs \\
BrO ) \\
$\frac{k e y \text { w o } d s}{1,1-d i f l u o r o-2-m e t h o x y p r o p a n e ~}$ \\
DFT \\
CFCs \\
BrO \\
\end{tabular}

\begin{abstract}
A B S T R A C T
An Insilco study was carried out on the thermochemistry, mechanism and kinetics of the Hydrogen abstraction reaction of 1,1-difluoro-2-methoxypropane $\left(\mathrm{CH}_{3} \mathrm{CH}\left(\mathrm{OCH}_{3}\right) \mathrm{CHF}_{2}\right)$ with the bromine monoxide radical (BrO) using the Density Functional Theory (DFT) based M06-2X/6311++ $G^{* *}$ method. The energy values were immediately improved via optimization at DFT/M06-2X/6-311++G(2df,2p) level (single-point calculations) of the reacting species involved. The Monte Carlo search on the investigating hydrofluoroether (HFE) showed nine conformers with the lowest global minimum conformer being predicted and considered for this work. The results of this study showed that the atmospheric oxidation reaction of $\mathrm{CH}_{3} \mathrm{CH}\left(\mathrm{OCH}_{3}\right) \mathrm{CHF}_{2}$ with the $\mathrm{BrO}$ radical proceeded in four (4) plausible reaction routes. The total experimental rate of $4.34 * 10^{-06} \mathrm{~cm}^{-3}$ molecule ${ }^{-1} \mathrm{sec}^{-1}$ for $\mathrm{HFE}+\mathrm{BrO}$ reaction was estimated with atmospheric lifetime $(A L T) /$ global warming potential $(G W P)$ of 1.80 years and 165.30 respectively. The $3 D$ potential energy surfaces (PES) for the reaction was however constructed at absolute temperature of $298.15 \mathrm{~K}$.
\end{abstract}

\section{R E S U M E N}

Se realizó un estudio de Insilco sobre la termoquímica, el mecanismo y la cinética de la reacción de abstracción de hidrógeno de 1,1-difluoro-2-metoxipropano $\left(\mathrm{CH}_{3} \mathrm{CH}\left(\mathrm{OCH}_{3}\right)\right.$ $\mathrm{CHF}_{2}$ ) con el radical de monóxido de bromo (BrO) utilizando la teoría de la función de densidad (DFT) basado en el método M06-2X/6-311++G**. Los valores de energía se mejoraron inmediatamente a través de la optimización a nivel de DFT / M06-2X / 6-311 ++ $G(2 d f, 2 p)$ (cálculos de punto único) de las especies reactivas implicadas. La búsqueda de Monte Carlo en el hidrofluoroéter investigador (HFE) mostró nueve confórmeros con el confórmero mínimo global más bajo que se predijo y se consideró para este trabajo. Los resultados de este estudio mostraron que la reacción de oxidación atmosférica de $\mathrm{CH}_{3} \mathrm{CH}$ $\left(\mathrm{OCH}_{3}\right) \mathrm{CHF}_{2}$ con el radical BrO procedió en cuatro (4) rutas de reacción plausibles. La tasa experimental total de $4.34 * 10-06 \mathrm{~cm}^{-3}$ molécula-1 seg-1 para la reacción $\mathrm{HFE}+\mathrm{BrO}$ se estimó con la vida atmosférica (ALT) / potencial de calentamiento global (GWP) de 1.80 años y 165.30, respectivamente. Sin embargo, las superficies de energía potencial $3 D(P E S)$ para la reacción se construyeron a una temperatura absoluta de 298,15 K. 


\section{NOMENCLA T URE}

ALT: Atmospheric lifetime

BrO: Bromine monoxide radical

CFCs: Chlorofluorocarbons

DFT: Density functional theory

GWP: Global warming potential

HFEs: Hydrofluoroethers

IRC: Intrinsic reaction coordinate

PC: Product complex

PES: Potential Energy Surface

RC: Reactant complex

TS: Transition state

\section{INTRODUCTION}

The less reactivity and easy liquefaction are two main chemical properties that qualify Chlorofluorocarbons (CFCs) as good raw materials in the production of foam blowing agents, electronic detergents, aerosols, deodorant sprays, refrigerators, paint sprays, cleaning agents, furniture polishes, propellants, semiconductors etc. (Deka and Mishra, 2014; Guo et al., 2018; Philip, 1996). Researchers have shown that CFCs derivatives pose environmental hazards to ozone by diffusing into stratosphere and deplete it at a rate faster than it can be replaced in the atmosphere (Baidya et al., 2017; Garfield, 1988; Molina and Rowland, 1974; Orkin et al., 1999; Papadimitriou et al., 2007; Rowland, 1996; Rohrer and Berresheim, 2006; Rowley and Ferracci, 2014; WMO, 2010). For this fact, international restrictions and warning were placed on usage of CFCs as agreed upon in the Montreal Protocol (Good et al., 1998; Ye at al., 2016). Instead, alternative compounds with less or no posing ability to ozone is recommended as substantial substitutes for the CFCs (Espinosa-Garcia, 2003; Galano et al., 2010; MWO, 2010). Hydrofluoroethers (HFEs) and hydrofluoroalcohols (HFAs) (Mabury et al., 2006; White and Martell, 2015), have been discovered as substantial substitutes for CFCs with numerous applications ranging from refrigeration, cleaning, foam blowing, propelling, painting, solvents, pesticides, varnishes in laboratories etc. (Deka and Mishra, 2014; Hashemi and Saheb, 2017; Hurley et al., 2004; Laszlo et al., 1997; Prather and Spivakovsky, 1990; Sako et al., 1996; Wang et al., 2009). The presence of -0 - linkage between these series increases their chemical reactivity in the atmosphere which accounts for the chemistry of their short lifetime and lesser atmospheric effects compare to CFCs (Baidya et al., 2017; Gour et al., 2016).

The study of $\mathrm{CH}_{3} \mathrm{CH}\left(\mathrm{OCH}_{3}\right) \mathrm{CHF}_{2}$ with $\mathrm{BrO}$ radicals is an important atmospheric oxidation reaction that will provide information on the tropospheric reactivity of HFEs and also help to find degradation pathways of HFEs in the atmosphere. Hence, it is very necessary/vital to dig into the atmospheric chemistry of the HFEs for their better understanding as substantial substitutes for CFCs and to determine more of their impacts on the environment.

Many experimental studies carried out on the related study of this kind only provided the overall rate constants but found it very difficult to reveal the actual mechanism and the true reaction picture especially when the reaction is multi channels. However, with computational study the detailed mechanism, thermochemistry of multi channels of reactions, the tunneling correction and overall rate constant can be estimated accurately and simultaneously. This as a modern computational chemistry technique is very simple, time and cost saver, accurate and very fast compares to wet laboratory method.

The main objective of this study was to make an Insilco study on reaction of $\mathrm{CH}_{3} \mathrm{CH}\left(\mathrm{OCH}_{3}\right) \mathrm{CHF}_{2}$ with $\mathrm{BrO}$ radical using computational techniques. And also aimed at studying the computational kinetics of $\mathrm{H}$-abstraction reaction of $\mathrm{CH}_{3} \mathrm{CH}\left(\mathrm{OCH}_{3}\right) \mathrm{CHF}_{2}$ by $\mathrm{BrO}$ radical which involves four (4) $\mathrm{H}-$ abstraction positions of $-\mathrm{CHF}_{2},-\mathrm{OCH}_{3},-\mathrm{CH}$ and $-\mathrm{CH}_{3}$ as shown in the chemical reactions R1-R4.

$$
\begin{aligned}
\mathrm{CH}_{3} \mathrm{CH}\left(\mathrm{OCH}_{3}\right) \mathrm{CHF}_{2}+\mathrm{BrO} \\
\rightarrow \mathrm{CH}_{3} \mathrm{CH}\left(\mathrm{OCH}_{3}\right) \mathrm{CF}_{2}+\mathrm{HOBr}
\end{aligned}
$$

$$
\begin{aligned}
\mathrm{CH}_{3} \mathrm{CH}\left(\mathrm{OCH}_{3}\right) \mathrm{CHF}_{2}+\mathrm{BrO} & \\
& \rightarrow \mathrm{CH}_{3} \mathrm{C}\left(\mathrm{OCH}_{3}\right) \mathrm{CHF}_{2}+\mathrm{HOBr}
\end{aligned}
$$

$$
\begin{aligned}
\mathrm{CH}_{3} \mathrm{CH}\left(\mathrm{OCH}_{3}\right) \mathrm{CHF}_{2}+\mathrm{BrO} & \\
& \rightarrow \mathrm{CH}_{3} \mathrm{CH}\left(\mathrm{OCH}_{2}\right) \mathrm{CHF}_{2}+\mathrm{HOBr}
\end{aligned}
$$

\section{$\mathrm{CH}_{3} \mathrm{CH}\left(\mathrm{OCH}_{3}\right) \mathrm{CHF}_{2}+\mathrm{BrO}$}

$$
\rightarrow \mathrm{CH}_{2} \mathrm{CH}\left(\mathrm{OCH}_{3}\right) \mathrm{CHF}_{2}+\mathrm{HOBr} \quad(\mathrm{R} 4)
$$

The study by Christensen et al., 1998 on HFE - 7200 $\left(\mathrm{C}_{4} \mathrm{~F}_{9} \mathrm{OC}_{2} \mathrm{H}_{5}\right)$ with $\mathrm{OH}$ radicals at $295 \mathrm{~K}$ revealed that HFE 7200 has $\mathrm{k}\left(\mathrm{OH}+\mathrm{n}-\mathrm{C}_{4} \mathrm{~F}_{9} \mathrm{OC}_{2} \mathrm{H}_{5}\right)=(6.4 \pm 0.7) * 10^{-14} \mathrm{~cm}^{-}$ ${ }^{3}$ molecule $^{-1} \mathrm{~s}^{-1}, \mathrm{k}\left(\mathrm{OH}+\mathrm{i}-\mathrm{C}_{4} \mathrm{~F}_{9} \mathrm{OC}_{2} \mathrm{H}_{5}\right)=(7.7 \pm 0.8) * 10^{-14} \mathrm{~cm}^{-}$ ${ }^{3}$ molecule ${ }^{-1} \mathrm{~s}^{-1}$ and atmospheric lifetime of 0.9 and 0.7 years respectively. Also, computational study of $\mathrm{H}$-abstraction reactions from $\mathrm{CH}_{3} \mathrm{OCH}_{2} \mathrm{CH}_{2} \mathrm{Cl} / \mathrm{CH}_{3} \mathrm{CH}_{2} \mathrm{OCH}_{2} \mathrm{CH}_{2} \mathrm{Cl}$ by $\mathrm{Cl}$ atom and $\mathrm{OH}$ radical showed that their atmospheric lifetime are 39 hrs. and 19 hrs. respectively. (Gour et al., 2016). Thus, the presence of an atom of $\mathrm{Br}, \mathrm{Cl}$, I etc. in an atmosphere is a chemical set back to ozone layer (Deka and Mishra, 2014; Laszlo et al., 1997; Wofsy et al., 1975; Yang et al., 2007).

To ascertain fluorinated ethers as substantial alternatives for CFCs, there is necessity for proper and several Insilco/wet laboratory studies on them so as to determine them as substantial candidates capable of replacing CFCs.

\section{MATERIALS AND METHODS}

\subsection{Samples used (HFEs and radical)}

1,1-difluoro-2-methoxypropane (HFE), BrO radical were used for this Insilco study (Anderson, 1987; Baidya et al., 2017; Hashemi \& Saheb, 2017; Schlager et al., 2012; MWO, 2010). The 3D structures of HFEs/radical were drawn using Spartan 14 v 112 suite licensed software (Spartan '14, 2013).

\subsection{Computational Procedures}

The Spartan 14 v 112 suite licensed software was used for all the electronic calculations. The geometry optimization of all chemical species involved in the reaction were carried out using density functional theory (DFT) based M06-2X method with the $6-311++\mathrm{G}^{* * *}$ basis set (Spartan '14, 2013). To improve the energy values, $6-311++\mathrm{G}(2 \mathrm{df}, 2 \mathrm{p})$ single-point calculations were immediately performed using same DFT method. Earlier related studies on computational kinetics proved that, theoretical thermochemistry and kinetics of reaction can be modeled accurately and provides reliable results when the DFT with M06-2X level of theory is employed (Baidya et al., 2017; De Carvalho and Roberto-Neto, 2018; Hashemi and Saheb, 2017; White and Martell, 2015). 
The minimum energy equilibrium structure obtained at each stationary point has all real frequencies meanwhile transition state possesses one imaginary frequency. The imaginary frequency in transition state corresponds to the coupling of stretching modes of the breaking $\mathrm{C}-\mathrm{H}$. Transformation from the reactant to product via the transition state (TS) along the minimum energy path was confirmed with the help of intrinsic reaction coordinate (IRC) calculations at the M06-2X level of DF theory (Baidya et al., 2017; Gour et al., 2016). IRC calculations confirmed the formation of pre and post-reaction complexes of the reactant/product molecule with the $\mathrm{BrO}$ radical or $\mathrm{HOBr}$ in both the entry and exit of each reaction channel.

The rate constants $(\mathrm{k})$ for $\mathrm{H}-\mathrm{abstraction}$ reactions were obtained from the reaction basic steps involved according to equation 5-6.

$H F E S+B r O \rightleftharpoons T S 1$

$\mathrm{TS} 1 \rightarrow \mathrm{P}+\mathrm{HOBr}$

The rate coefficients $(\mathrm{k})$, change in enthalpy $\left(\Delta_{\mathrm{r}} \mathrm{H}^{\mathrm{o}}{ }_{\mathrm{rnn}}\right)$, change in free Gibb's energy $\left(\Delta_{\mathbf{r}} G^{o}{ }_{\text {rxn }}\right)$ and change in energy $\left(\Delta_{\mathbf{r}} \mathrm{E}_{\text {rxn }}^{\mathrm{o}}\right)$ of each radical's reaction channels were computed according to the view of Roussel, 2009; Siaka and his coworkers in 2017; Truhlar and his coworkers in 1996 as in equation $7-10$.

$$
k=\sigma_{r} \Gamma \frac{k_{B} T}{h} \frac{Q_{T S}^{\dagger}}{Q_{R}} e^{-\frac{\Delta E^{\ddagger}}{R T}}
$$

$\Delta_{r} H_{r x n}^{o}=\sum_{\text {prod. }} \Delta_{f} H_{\text {prod. }}-\sum_{\text {react. }} \Delta_{f} H_{\text {react }}$

$\Delta_{r} G_{r x n}^{o}=\Delta_{r} H_{r x n}^{o}-T \Delta_{r} S_{r x n}^{o}$

$\Delta_{r} E_{\text {rxn }}^{o}=\sum_{\text {prod. }} \Delta_{f} E_{\text {prod. }}-\sum_{\text {react. }} \Delta_{f} E_{\text {react }}$

The change in enthalpy as well as Gibb's free energy of each transition states were estimated using expressions 11-12

$\Delta \mathrm{H}^{\#}=\sum_{\text {prod. }} \Delta_{\mathrm{f}} \mathrm{H}^{\#}-\sum_{\text {react. }} \Delta_{\mathrm{f}} \mathrm{H}_{\text {react. }}$

$\Delta \mathrm{G}^{\#}=\Delta \mathrm{H}^{\#}-T \Delta \mathrm{S}^{\#}$

The total rate coefficient was calculated using equation 13

$\mathrm{k}=\mathrm{k}_{\mathrm{R}_{1}}+\mathrm{k}_{\mathrm{R}_{2}}+\mathrm{k}_{\mathrm{R}_{3}}+\mathrm{k}_{\mathrm{R}_{4}}$

The branching ratios (BR) for the Hydrogen abstraction reaction channels of each radical, which is reported by Deka and Mishra, 2014 to have been represented the individual contribution of a reaction channel toward overall reaction rate were computed using an expression 14.

Branching ratio $=\frac{k}{k_{\text {Total }}} * 100$

The $E_{a}$ values of all reaction channels for each radical were determined using expression 15.

$E_{a}=\Delta G^{\dagger}=\Delta G^{\#}-\sum \Delta G_{r}$

The atmospheric lifetime of HFE + BrO radical was computed using an expression 16

$\tau_{\text {eff }}=\tau_{\text {Bro }}$

The 100-time horizon Global warming potential (GWP) of HFE is estimated in accordance to the view of Baidya and his colleagues in 2017 as expressed in equation 17
$G W P_{i}(H)=\frac{\int_{O}^{H} R F_{i}(t) d t}{\int_{O}^{H} R F_{C O_{2}}(t) d t}=\frac{A G W P_{i}(H)}{A G W P_{C O_{2}}(H)}$

\section{RESULTS AND DISCUSSION}

\subsection{Sample conformers}

Fig. 1 shows the nine possible conformers of 1,1difluoro-2-methoxypropane molecule ranging from the lowest to highest energy conformers.

Monte Carlo's search was (conformational analysis) performed on $\mathrm{H}_{3} \mathrm{CCH}\left(\mathrm{OCH}_{3}\right) \mathrm{CHF}_{2}$ molecule by selecting Set up/Calculation/Conformational search under the application menu. MMFF force field was selected with maximum iteration number entered under the Mini tab. The default (1000) for maximum number was activated from the conformational search tab. The operation was then started with file name given. The result of this operational search showed nine conformers as illustrated in Fig. 1. From the analysis, conformer A $(0.10 \mathrm{kcal}$ $\mathrm{mol}^{-1}$ ) had the lowest global minimum predicted. This search was aimed at identifying the possible conformers of $\mathrm{H}_{3} \mathrm{CCH}\left(\mathrm{OCH}_{3}\right) \mathrm{CHF}_{2}$ molecule with their respective global minima and to select the most stable conformer. Conformers with higher global minima were not considered since they are unstable (Baidya et al., 2017). The generated conformers were arranged in Fig. 1 in order of increasing in their energy stabilities. So, with reference to Fig. 1, conformer I $(2.88 \mathrm{kcal}$ $\mathrm{mol}^{-1}$ ) has the highest energy predicted and thus the most unstable.

Fig. 2 shows the 3D structures of the optimized reacting species while Fig. 3 depicts 3D PES of $\mathrm{H}$-atom abstraction from HFE with the radical.

Table 1 and $\mathbf{3}$ show the results of calculated energies and enthalpies (in $\mathrm{kJ} \mathrm{mol}^{-1}$ ) of the reacting species with $\mathrm{BrO}$ radical at DFT/M06-2X/6-311++G ${ }^{* *}$ level while the Table 2 and 4 show the results on single-point calculation which was aimed at improving the reacting species energies as well as their enthalpies (in $\mathrm{kJ} \mathrm{mol}^{-1}$ ) at DFT/M06-2X/6-311++G(2df,2p) level.

Table 5 shows the thermodynamics calculation results of $\mathrm{H}$-abstraction reaction routes that were performed at DFT/M06-2X/6-311++G** level with BrO radical. These results show that reaction through the routes $\mathrm{R} 1$ and $\mathrm{R} 2$ were exothermic in nature i.e. $\Delta_{\mathrm{r}} \mathrm{H}^{\mathrm{o}}{ }_{\text {rxn }}<0$ and thermodynamically favorable while R3 and R4 routes followed endothermic reactions $\left(\Delta_{\mathrm{r}} \mathrm{H}^{\mathrm{o}}{ }_{\text {rxn }}>0\right)$, thus the routes ( $\mathrm{R} 2$ and $\left.\mathrm{R} 3\right)$ were thermodynamically unfavored. The $\Delta_{\mathrm{r}} \mathrm{E}^{\mathrm{o}}{ }_{\mathrm{rxn}}$ across the four routes of this reaction proved that $\mathrm{R} 2$ and $\mathrm{R} 4$ routes have high possibility of $\mathrm{H}$-abstraction than R1 and R3 since they (R2 and $\mathrm{R} 4)$ had lower $\Delta_{\mathrm{r}} \mathrm{E}^{\mathrm{o}}{ }_{\text {rxn }}$. Also, the negative values of $\Delta_{\mathrm{r}} \mathrm{G}^{\mathrm{o}}{ }_{\text {rxn }}$ across all the reaction routes indicated that the obtained products were thermodynamically feasible. Hence, R2 is more feasible. However, an improved and further thermodynamics single-point calculation (DFT/M06-2X/6-311++G(2df,2p)) results in Table 6 illustrates the endothermic nature of reaction via R1 and R4 but exothermic along $\mathrm{R} 2$ and $\mathrm{R} 3$ respectively. Also, $\Delta_{\mathrm{r}} \mathrm{G}^{\mathrm{o}}{ }_{\mathrm{rxn}}$ across reaction routes revealed that, the product obtained were thermodynamically feasible (R2 also more feasible).

Tables 7 and 8 reveal that reaction of $\mathrm{BrO}$ radical with the sample proceeded in two steps: (1) transition state formation and (2) product formation. According to the Gibb's free energies of the two steps computed, the rate determining step (RDS) of 
each reaction channel was identified on the basis of $\Delta \mathrm{G}_{1}>\Delta \mathrm{G}^{\#}$. Thus, the second steps i.e. product formation were the RDS. The rate determining steps are the slowest steps in the reaction between the HFE and the radical specie that was investigated.

The results from Tables $\mathbf{9}$ and $\mathbf{1 0}$ show that there were four $\mathrm{H}$-atom abstraction carbon sites of $\mathrm{H}_{3} \mathrm{CCH}\left(\mathrm{OCH}_{3}\right) \mathrm{CHF}_{2}$ which are $-\mathrm{CHF}_{2},-\mathrm{CH},-\mathrm{OCH}_{3}$ and $-\mathrm{CH}_{3}$ groups. This eventually led to formation of four transition states (TS1, TS2, TS3 and TS4) as the sample was reacting with BrO radical. For each transition state of the radical investigated with sample, the $\mathrm{C}-\mathrm{H}$ bond of the abstracting hydrogen atom and newly formed bond between $\mathrm{H}$ and $\mathrm{O}$ atoms were noted. The intrinsic reaction coordinates (IRC) calculation performed on all transition states at the same level were characterized by the occurrence of an imaginary frequencies as illustrated in same Tables (9 and $\mathbf{1 0}$ respectively). This therefore proved that there exists chemical connection between transition states and reactants as well as products of all reaction channels for radical involved. Also, during entrance and exit channels (R1-R4) of this reaction, prereactive complexes ( $\mathrm{RC} 1, \mathrm{RC} 2, \mathrm{RC} 3$ and $\mathrm{RC} 4)$ and postreactive complexes (PC1, PC2, PC3 and PC4) formed have been validated as recommended by Baidya and his coworkers in 2017. In addition, formation of hydrogen bond was observed in the pre-reactive and post-reactive complexes between Oxygen atom of $\mathrm{BrO}$ radical with $\mathrm{H}$-atom in the $\mathrm{H}_{3} \mathrm{CCH}\left(\mathrm{OCH}_{3}\right) \mathrm{CHF}_{2}$ which was as a result of weak force of attraction. Thus, this implies that all the reaction channels can even proceed in an indirect mechanism manner.

Table 11 illustrates the variations in $\mathrm{BR}_{\mathrm{BrO}}, \mathrm{k}_{\mathrm{BrO}}$, as well as $\mathrm{Ea}_{\mathrm{BrO}}$ of sample's reaction with $\mathrm{BrO}$ radical investigated. The $\mathrm{k}_{\mathrm{BrO}}$ along the channels $\mathrm{R} 1$ and $\mathrm{R} 2$ were greater than the $\mathrm{k}_{\mathrm{BrO}}$ across channels $\mathrm{R} 3$ as well as $\mathrm{R} 4$. The extremely higher $\mathrm{BR}_{\mathrm{BrO}}$ value along channel $\mathrm{R} 1$ is due to the chemical influence of Fluorine atoms at $\mathrm{C} 1$.

\subsection{Rate constant computation}

The rate constants for reaction channels R1, R2, R3 and R4 were computed using the TST equation (7) couple with Wigner's H-abstraction tunneling correction at an absolute temperature of $298.15 \mathrm{~K}$. The lowest energy conformer of $\mathrm{H}_{3} \mathrm{CCH}\left(\mathrm{OCH}_{3}\right) \mathrm{CHF}_{2}$ molecule was considered for $\mathrm{H}$ abstraction reaction with atmospheric radical $(\mathrm{BrO})$. The

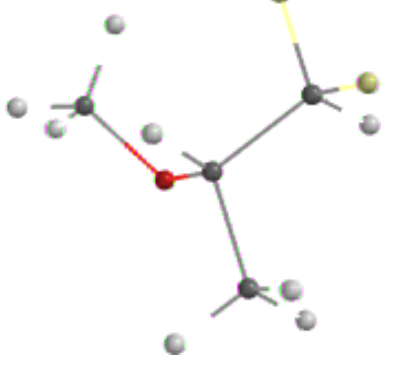

A

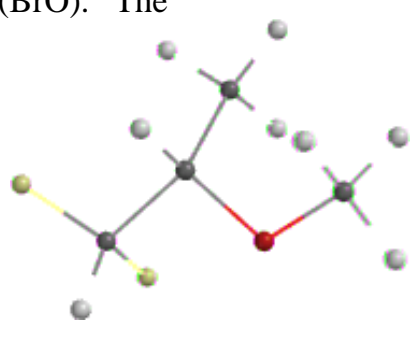

$\mathbf{B}$ sample's reaction with radical passed through four channels with transition states: TS1, TS2, TS3 and TS4 respectively been formed. The total rate constant value at $298.15 \mathrm{~K}$ was estimated according to an expression (13). The computed rate constant values obtained using an improved single-point calculation (DFT/M06-2X/6-311++G(2df,2p) were given in Table 11. The total estimated rate for $\mathrm{HFE}+\mathrm{BrO}$ was $4.34 * 10^{-06} \mathrm{~cm}^{-3}$ molecule ${ }^{-1} \mathrm{sec}^{-1}$.

\subsection{Atmospheric implications}

The atmospheric lifetime of $\mathrm{H}_{3} \mathrm{CCH}\left(\mathrm{OCH}_{3}\right) \mathrm{CHF}_{2}$ $\left(\tau_{\text {eff }}\right)$ was estimated via the assumption that its atmospheric removal is through its reaction with $\mathrm{BrO}$ radical. So, it was estimated using expression (16). i.e.

$\tau_{\text {eff }}=\tau_{\text {BrO }}$

Where, $\tau_{\mathrm{BrO}}=\left(\mathrm{k}_{\mathrm{BrO}} *[\mathrm{BrO}]\right)^{-1}$

If the global average atmospheric $\mathrm{BrO}$ radical concentration is taken as $3.0 * 10^{7}$ molecule $\mathrm{cm}^{-3}$ and the calculated total value of $\mathrm{k}_{\mathrm{BrO}}$ is $4.34 * 10^{-06} \mathrm{~cm}^{-3}$ molecule $\mathrm{sec}^{-1}$. The atmospheric lifetime of $\mathrm{H}_{3} \mathrm{CCH}\left(\mathrm{OCH}_{3}\right) \mathrm{CHF}_{2}$ have been recorded as 1.8 years.

\subsection{Global warming potentials (GWPs)}

The global warming potentials of $\mathrm{H}_{3} \mathrm{CCH}\left(\mathrm{OCH}_{3}\right) \mathrm{CHF}_{2}$ molecule was estimated at the DFT/M06-2X/6-311++G(2df,2p) based on the integrated-time radiative forcing spontaneous radiation of $1 \mathrm{~kg} \mathrm{CO}_{2}$ as a reference gas (Baidya et al., 2017; Orkin et al., 1999). The HFE's GWPs was found relative to the $\mathrm{CO}_{2}$ reference information using an equation 17. The GWPs obtained for HFE in 100-year time horizon is 165.30 while the GWP for CFC-11, the most vital CFC with numerous applications (100-year time horizon) is reported as 4600 (Baidya et al., 2017). In comparison, $\mathrm{H}_{3} \mathrm{CCH}\left(\mathrm{OCH}_{3}\right) \mathrm{CHF}_{2}$ with shorter estimated atmospheric lifetime and lower GWP is of lesser atmospheric and environmental effects than CFCs.

\section{FIGURES}



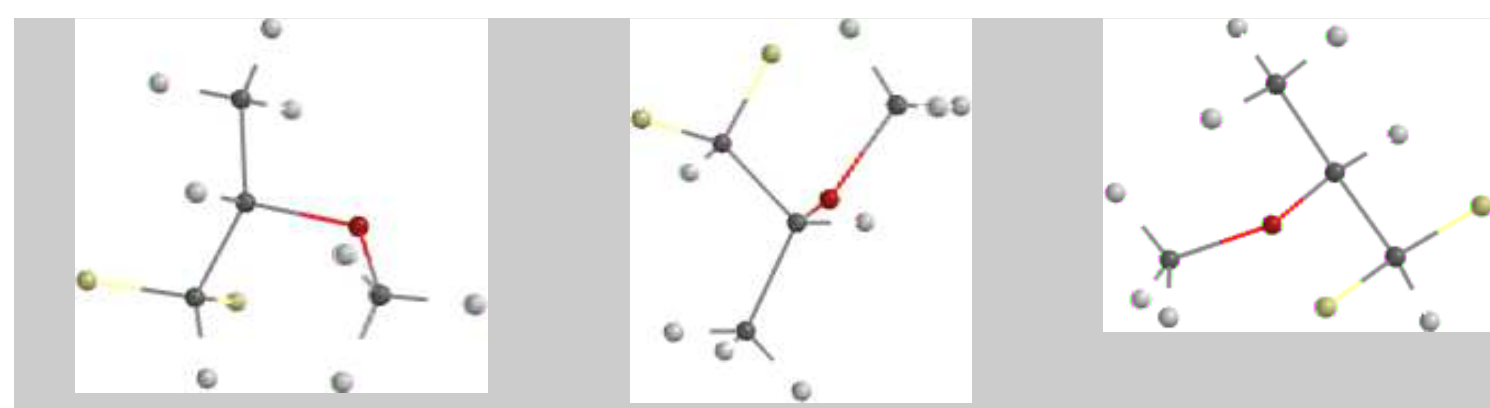

D

E

0

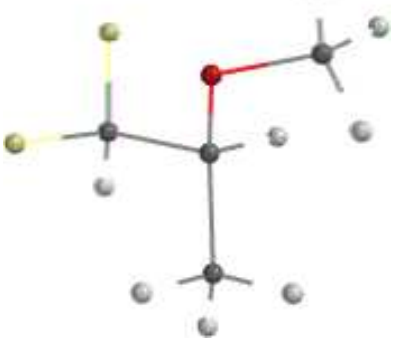

G

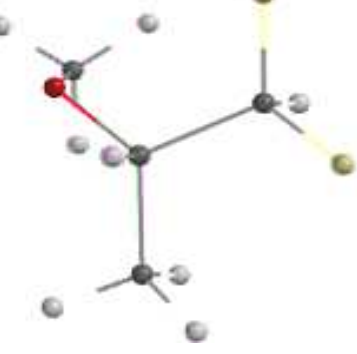

H

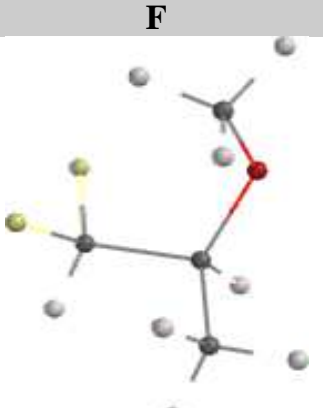

I

Fig. 1- 3D structures of the possible conformers of 1,1-difluoro-2-methoxypropane molecule

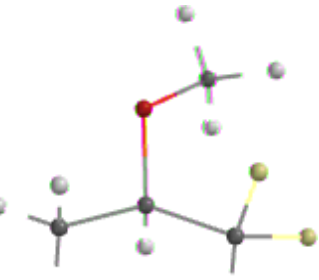

HFE

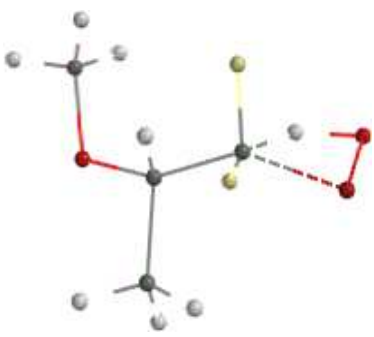

PC1

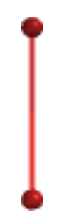

BrO radical

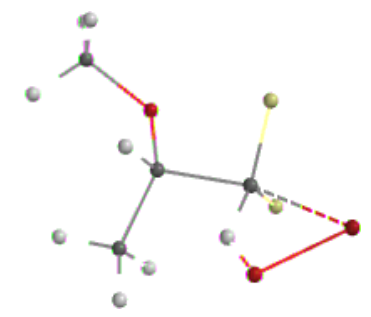

$\mathrm{RC} 1$

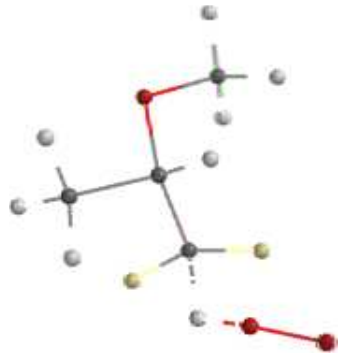

TS1

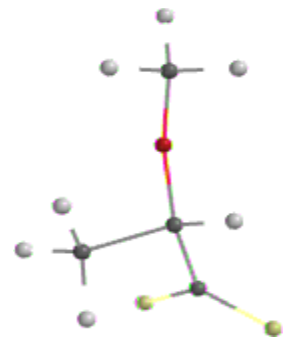

P1

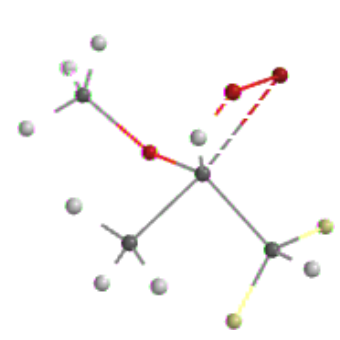

$\mathrm{RC} 2$

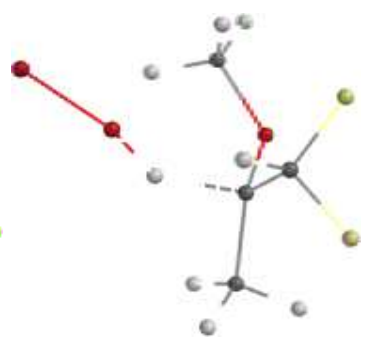

TS2

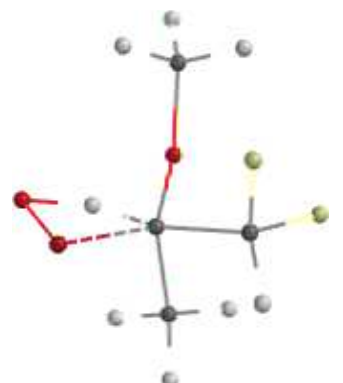

PC2

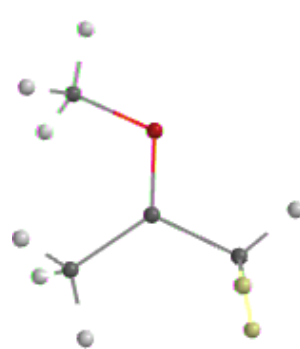

P2

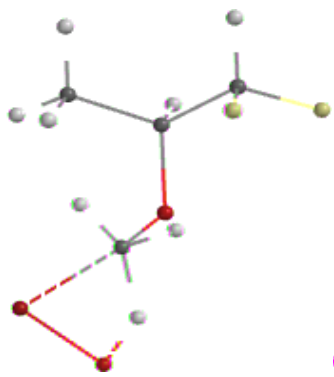

RC3

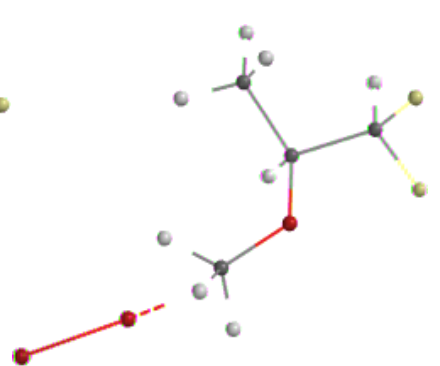

TS3 


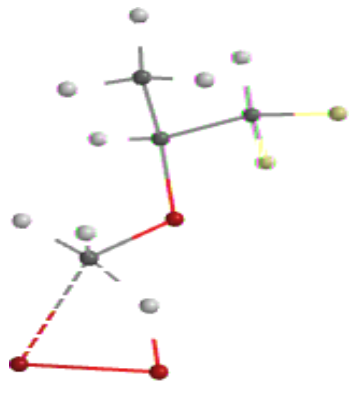

PC3

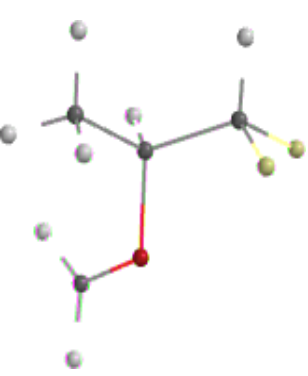

P3

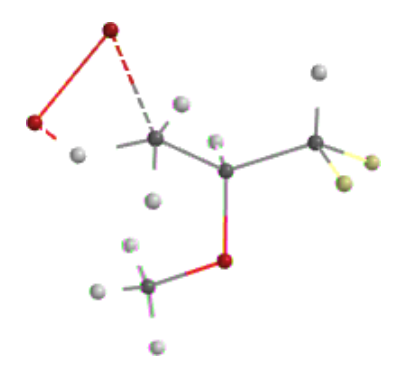

RC4

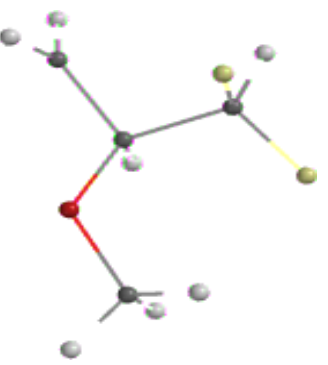

P4

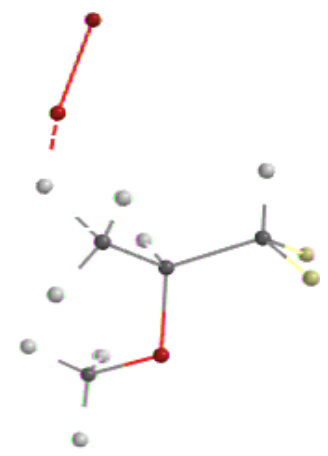

TS4

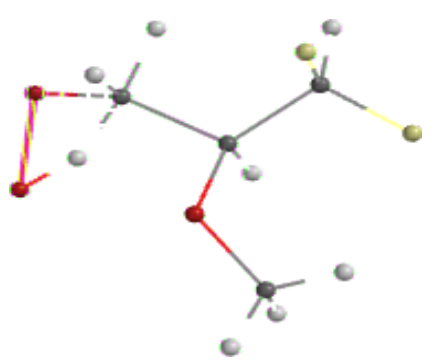

PC4

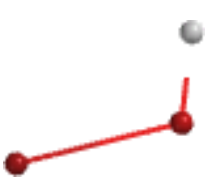

$\mathrm{HOBr}$

Figure 2- 3D structures of optimized reacting species with BrO radical.

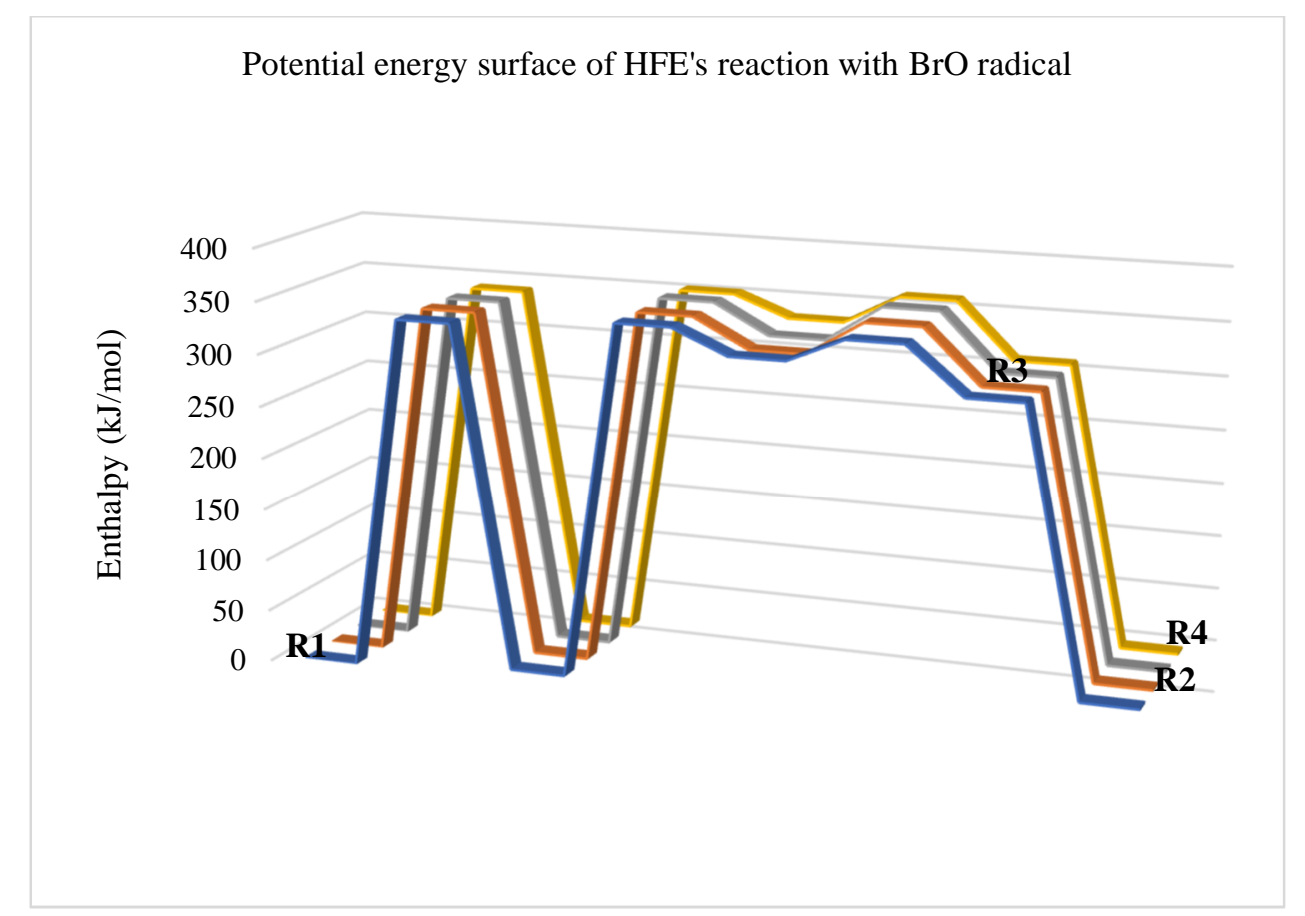

Figure 3- HFE vs BrO radical H-abstraction reaction channels (DFT/M06-2X/6-311++G(2df,2p)). 


\section{TABLES}

Table 1 - Calculated energy $\left(\mathrm{kJ} \mathrm{mol}^{-1}\right)$ of the optimized reacting species with BrO radical (298 K) at DFT/M06-2X/6$311++G^{* *}$ level of theory.

\begin{tabular}{|c|c|c|c|c|c|c|c|}
\hline $\begin{array}{l}\text { Reaction } \\
\text { routes }\end{array}$ & $\begin{array}{c}\mathrm{HFE}\left(\mathrm{kJ} \mathrm{mol}^{-}\right. \\
1)\end{array}$ & $\begin{array}{l}\text { Radical (kJ } \\
\left.\mathrm{mol}^{-1}\right)\end{array}$ & $\begin{array}{l}\mathrm{RC}(\mathrm{kJ} \\
\left.\mathrm{mol}^{-1}\right)\end{array}$ & $\mathrm{TS}\left(\mathrm{kJ} \mathrm{mol}^{-1}\right)$ & $\mathrm{PC}\left(\mathrm{kJ} \mathrm{mol}^{-1}\right)$ & $\begin{array}{c}\text { PMajor }_{\text {Majol }} \\
\left(\mathrm{kJ} \mathrm{mol}^{-1}\right)\end{array}$ & $\begin{array}{c}\text { PMinor } \\
\left(\mathrm{kJ} \mathrm{mol}^{-1}\right)\end{array}$ \\
\hline $\mathrm{R} 1$ & -1134.32 & -6955.47 & -8089.87 & -8089.32 & -8089.89 & -1131.86 & -6956.99 \\
\hline $\mathrm{R} 2$ & -1134.32 & -6955.47 & -8089.85 & -8089.42 & -8090.22 & -1131.95 & -6956.99 \\
\hline R3 & -1134.32 & -6955.47 & -8089.66 & -8089.52 & -8090.32 & -1131.89 & -6956.99 \\
\hline $\mathrm{R} 4$ & -1134.32 & -6955.47 & -8089.89 & -8089.62 & -8090.28 & -1131.94 & -6956.99 \\
\hline
\end{tabular}

Table 2 - Improved Calculated energy $\left(\mathrm{kJ} \mathrm{mol}^{-1}\right)$ of the optimized reacting species with BrO radical (298 K) at DFT/M06$2 X / 6-311++G(2 d f, 2 p)$ level of theory.

\begin{tabular}{lccccccc}
$\begin{array}{c}\text { Reaction } \\
\text { routes }\end{array}$ & $\begin{array}{c}\mathrm{HFE}\left(\mathrm{kJ} \mathrm{mol}^{-}\right. \\
1\end{array}$ & $\begin{array}{c}\text { Radical }(\mathrm{kJ} \\
\left.\mathrm{mol}^{-1}\right)\end{array}$ & $\begin{array}{c}\mathrm{RC}(\mathrm{kJ} \\
\left.\mathrm{mol}^{-1}\right)\end{array}$ & $\mathrm{TS}\left(\mathrm{kJ} \mathrm{mol}^{-1}\right)$ & $\mathrm{PC}\left(\mathrm{kJ} \mathrm{mol}^{-1}\right)$ & $\begin{array}{c}\mathrm{PMajor} \\
\left(\mathrm{kJ} \mathrm{mol}^{-1}\right)\end{array}$ & $\begin{array}{c}\mathrm{PMinor} \\
\left(\mathrm{kJ} \mathrm{mol}^{-1}\right)\end{array}$ \\
R1 & -1134.39 & -6955.56 & -8089.85 & -8089.30 & -8089.78 & -1131.94 & -6957.08 \\
R2 & -1134.39 & -6955.56 & -8089.84 & -8089.40 & -8090.21 & -1132.02 & -6957.08 \\
R3 & -1134.39 & -6955.56 & -8089.86 & -8089.49 & -8090.35 & -1131.96 & -6957.08 \\
R4 & -1134.39 & -6955.56 & -8089.88 & -8089.59 & -8090.30 & -1132.02 & -6957.08 \\
\hline
\end{tabular}

$\mathrm{P}_{\text {Major: }}$ Major product $=$ hydrofluoroether radical $\& \mathrm{P}_{\text {Minor }}$ : Minor product $=\mathrm{HOBr}$

Table 3 - Calculated enthalpy $\left(\mathrm{kJ} \mathrm{mol}^{-1}\right)$ of the optimized reacting species with BrO radical (298 K) at DFT/M06-2X/6$311++G^{* *}$ level of theory.

\begin{tabular}{llllllll}
$\begin{array}{c}\text { Reaction } \\
\text { routes }\end{array}$ & $\begin{array}{c}\mathrm{HFE}(\mathrm{kJ} \mathrm{mol} \\
1\end{array}$ & $\begin{array}{c}\text { Radical }(\mathrm{kJ} \\
\left.\mathrm{mol}^{-1}\right)\end{array}$ & $\begin{array}{c}\mathrm{RC}(\mathrm{kJ} \\
\left.\mathrm{mol}^{-1}\right)\end{array}$ & $\mathrm{TS}\left(\mathrm{kJ} \mathrm{mol}^{-1}\right)$ & $\mathrm{PC}\left(\mathrm{kJ} \mathrm{mol}^{-1}\right)$ & $\begin{array}{c}\mathrm{P}_{\text {Major }} \\
\left(\mathrm{kJ} \mathrm{mol}^{-1}\right)\end{array}$ & $\begin{array}{c}\mathrm{PMinor} \\
\left(\mathrm{kJ} \mathrm{mol}^{-1}\right)\end{array}$ \\
R1 & 338.40 & 12.54 & 349.61 & 327.38 & 352.09 & 307.06 & 44.25 \\
R2 & 338.40 & 12.54 & 349.28 & 322.22 & 356.49 & 304.84 & 44.25 \\
R3 & 338.40 & 12.54 & 351.70 & 323.40 & 361.40 & 306.76 & 44.25 \\
R4 & 338.40 & 12.54 & 349.64 & 330.17 & 361.75 & 307.26 & 44.25 \\
\hline
\end{tabular}

Table 4 - Improved Calculated enthalpy $\left(\mathrm{kJ} \mathrm{mol}^{-1}\right)$ of the optimized reacting species with BrO radical (298 K) at DFT/M062X/6-311++G(2df,2p) level of theory.

\begin{tabular}{|c|c|c|c|c|c|c|c|}
\hline $\begin{array}{l}\text { Reaction } \\
\text { routes }\end{array}$ & $\begin{array}{c}\mathrm{HFE}\left(\mathrm{kJ} \mathrm{mol}^{-}\right. \\
\left.{ }^{1}\right)\end{array}$ & $\begin{array}{l}\text { Radical (kJ } \\
\left.\text { mol }^{-1}\right)\end{array}$ & $\begin{array}{l}\mathrm{RC}(\mathrm{kJ} \\
\left.\mathrm{mol}^{-1}\right)\end{array}$ & $\mathrm{TS}\left(\mathrm{kJ} \mathrm{mol}^{-1}\right)$ & $\mathrm{PC}\left(\mathrm{kJ} \mathrm{mol}^{-1}\right)$ & $\begin{array}{c}\text { PMajor }_{\text {Mol }} \\
\left(\mathrm{kJ} \mathrm{mol}^{-1}\right)\end{array}$ & $\begin{array}{c}\mathrm{P}_{\text {Minor }} \\
\left(\mathrm{kJ} \mathrm{mol}^{-1}\right)\end{array}$ \\
\hline $\mathrm{R} 1$ & 339.15 & 12.86 & 350.88 & 328.39 & 351.26 & 307.98 & 44.63 \\
\hline $\mathrm{R} 2$ & 339.15 & 12.86 & 350.45 & 323.45 & 355.90 & 305.97 & 44.63 \\
\hline R3 & 339.15 & 12.86 & 353.56 & 325.78 & 359.89 & 307.16 & 44.63 \\
\hline R4 & 339.15 & 12.86 & 351.34 & 331.80 & 359.28 & 307.49 & 44.63 \\
\hline
\end{tabular}

Table 5 - Thermodynamics data on H-abstraction reaction channels (R1-R4) of the HFE with BrO radical calculated at DFT/M06-2X/6-311++G** Density Functional Theory.

\begin{tabular}{lllll}
$\begin{array}{l}\text { Reaction } \\
\text { routes }\end{array}$ & $\Delta_{\mathrm{r}} \mathrm{H}^{\mathrm{o}}{ }_{\mathrm{rxn}}\left(\mathrm{kJ} \mathrm{mol}^{-1}\right)$ & $\Delta_{\mathrm{r}} \mathrm{G}^{\mathrm{o}}{ }_{\mathrm{rxn}}\left(\mathrm{kJ} \mathrm{mol}^{-1}\right)$ & $\Delta_{\mathrm{r}} \mathrm{E}^{\mathrm{o}}{ }_{\mathrm{rxn}}\left(\mathrm{kJ} \mathrm{mol}^{-1}\right)$ & $\Delta \boldsymbol{G}^{\dagger}$ \\
$\mathrm{R} 1$ & & & \\
$\mathrm{R} 2$ & -0.37 & -4.93 & 940.75 & 205.31 \\
$\mathrm{R} 3$ & -1.85 & -7.81 & 857.21 & 200.49 \\
$\mathrm{R} 4$ & 0.07 & -4.41 & 907.77 & 198.11 \\
\hline
\end{tabular}


Table 6 - Thermodynamics data on H-abstraction reaction channels (R1-R4) of the HFE with BrO radical calculated at DFT/M06-2X/6-311++G(2df,2p) Density Functional Theory.

\begin{tabular}{lllll}
$\begin{array}{l}\text { Reaction } \\
\text { routes }\end{array}$ & $\Delta_{\mathrm{r}} \mathrm{H}^{\mathrm{o}}{ }_{\mathrm{rxn}}\left(\mathrm{kJ} \mathrm{mol}^{-1}\right)$ & $\Delta_{\mathrm{r}} \mathrm{G}_{\mathrm{rxn}}^{\mathbf{0}}\left(\mathrm{kJ} \mathrm{mol}^{-1}\right)$ & $\Delta_{\mathrm{r}} \mathrm{E}_{\mathrm{rxn}}^{\mathrm{o}}\left(\mathrm{kJ} \mathrm{mol}^{-1}\right)$ & $\Delta \boldsymbol{G}^{\dagger}$ \\
$\mathrm{R} 1$ & & & \\
$\mathrm{R} 2$ & 0.60 & -4.22 & 928.21 & 205.62 \\
$\mathrm{R} 3$ & -1.41 & -7.63 & 847.31 & 201.42 \\
$\mathrm{R} 4$ & -0.22 & -5.00 & 901.84 & 201.08 \\
\hline
\end{tabular}

Table 7 - DFT/M06-2X/6-311++G** thermodynamics parameters for the steps involved in the four HFEs reaction channels (R1-R4) with BrO radical

\begin{tabular}{lllll} 
Reaction routes & $\Delta \mathrm{H}^{\#}\left(\mathrm{~kJ} \mathrm{~mol}^{-1}\right)$ & $\Delta \mathrm{G}^{\#}\left(\mathrm{~kJ} \mathrm{~mol}^{-1}\right)$ & $\Delta \mathrm{H}_{1}\left(\mathrm{~kJ} \mathrm{~mol}^{-1}\right)$ & $\Delta \mathrm{G}_{1}\left(\mathrm{~kJ} \mathrm{~mol}^{-1}\right)$ \\
R1 & -23.56 & -150.55 & 23.93 & 103.06 \\
$\mathrm{R} 2$ & -28.72 & -158.38 & 26.87 & 102.79 \\
R3 & -27.54 & -157.24 & 27.61 & 102.09 \\
R4 & -20.77 & -145.56 & 21.34 & 103.18 \\
\hline
\end{tabular}

Table 8 - DFT/M06-2X/6-311++G(2df,2p) thermodynamics parameters for the steps involved in the four HFEs reaction channels (R1-R4) with BrO radical

\begin{tabular}{lllll} 
Reaction routes & $\Delta \mathrm{H}^{\#}\left(\mathrm{~kJ} \mathrm{~mol}^{-1}\right)$ & $\Delta \mathrm{G}^{\#}\left(\mathrm{~kJ} \mathrm{~mol}^{-1}\right)$ & $\Delta \mathrm{H}_{1}\left(\mathrm{~kJ} \mathrm{~mol}^{-1}\right)$ & $\Delta \mathrm{G}_{1}\left(\mathrm{~kJ} \mathrm{~mol}^{-1}\right)$ \\
R1 & -23.62 & -150.61 & 24.22 & 102.77 \\
R2 & -28.56 & -158.22 & 29.16 & 100.50 \\
R3 & -26.23 & -155.93 & 26.83 & 102.87 \\
R4 & -20.21 & -145.00 & 20.81 & 103.98 \\
\hline
\end{tabular}

$\Delta \mathrm{G}^{\#}=$ Gibb's free energy of transition state, $\Delta \mathrm{G}_{1}=$ Gibb's free energy of product formation

$\Delta \mathrm{H}^{\#}=$ Enthalpy of transition state formation, $\Delta \mathrm{H}_{1}=$ Enthalpy of product formation

Table 9 - IRC calculation results on transition states of each reaction channel for BrO radical at DFT/M06-2X/6-311++G**

\begin{tabular}{lll} 
Reaction routes & Transition states & $\begin{array}{l}\text { Intrinsic reaction coordinate } \\
\left(\text { IRC) in } \mathrm{cm}^{-1}\right.\end{array}$ \\
R1 & TS1 & $\mathrm{i} 418$ \\
R2 & TS2 & $\mathrm{i} 369$ \\
R3 & TS3 & $\mathrm{i} 297$ \\
R4 & TS4 & i180 \\
\hline
\end{tabular}

Table 10 - IRC calculation results on transition states of each reaction channel for BrO radical at DFT/M06-2X/6$311++G(2 d f, 2 p)$

\begin{tabular}{lll} 
Reaction routes & Transition states & $\begin{array}{l}\text { Intrinsic reaction coordinate } \\
\left(\text { IRC) in } \mathrm{cm}^{-1}\right.\end{array}$ \\
R1 & TS1 & $\mathrm{i} 520$ \\
R2 & TS2 & $\mathrm{i} 450$ \\
R3 & TS3 & i397 \\
R4 & TS4 & i280 \\
\hline
\end{tabular}

Table 11 - BR, $k$ and $E_{a}$ of $H$-abstraction reaction of $\mathrm{HFE}$ with BrO radical at DFT/M06-2X/6-311++G(2df,2p)

\begin{tabular}{llll} 
Reaction routes & $\mathrm{BR}_{\mathrm{BrO}}$ & $\begin{array}{l}\mathrm{k}_{\mathrm{BrO}} \\
\left(\mathrm{cm}^{-3} \mathrm{molecule}^{-1} \mathrm{sec}^{-1}\right)\end{array}$ & $\mathrm{E}_{\mathrm{aBro}}\left(\mathrm{kJ} \mathrm{mol}^{-1}\right)$ \\
$\mathrm{R} 1$ & 94.50 & $4.10^{*} 10^{-06}$ & 29.65 \\
$\mathrm{R} 2$ & 2.53 & $1.10^{*} 10^{-07}$ & 22.04 \\
$\mathrm{R} 3$ & 1.80 & $7.80^{*} 10^{-08}$ & 24.33 \\
$\mathrm{R} 4$ & 1.18 & $5.10^{*} 10^{-08}$ & 35.26 \\
\hline
\end{tabular}




\section{CONCLUSION}

In this Insilco study, an oxidation reaction mechanism of 1,1-difluoro-2-methoxypropane with the $\mathrm{BrO}$ radical was investigated using two different levels of DFT (M06-2X/6$311++\mathrm{G}^{* *}$ and M06-2X/6-311++G(2df,2p). This resulted to Habstraction from the molecule which was more favored at $-\mathrm{OCH}\left(\mathrm{CH}_{3}\right)$ carbon site. The whole reaction was found to proceeded in four plausible reaction channels (R1, R2, R3 and R4) with R2 being thermodynamically and kinetically most favorable channel. An intrinsic reaction coordinate (IRC) calculation carried out proved the transition states observed via each reaction channel as chemical species with all chemical properties to generate a pathway that can lead to the reactants and then to the products. The total rate constant of $4.34 * 10^{-06}$ $\mathrm{cm}^{-3}$ molecule ${ }^{-1} \mathrm{sec}^{-1}$ was reported for this study at DFT/M062X/6-311++G(2df,2p) level with an atmospheric lifetime (ALT) and GWP of 1.8 years and 165.30 respectively. Based on the results obtained, it was concluded that fluorinated HFE investigated can serves as a good substantial substitute for CFCs due to its short atmospheric lifetime and lower GWP.

\section{ACKNOWLEDGEMENT}

Mohammed Rufai Abubakar acknowledges the financial support of Petroleum Technology Development Fund (PTDF), Abuja, Nigeria, for providing a PTDF M.Sc. award (Award Letter No: PTDF/ED/LSS/MSc/MRA/244/17).

\section{R EFER E N C E S}

ANDERSON, J.G. FREE RADICALS IN THE EARTH'S ATMOSPHERE: Their Measurement and Interpretation. Ann. Rev. Phys. Chem., v. 38, p. 489 $-520,1987$.

BAIDYA, B.; LILY, M.; CHANDRA, A.K. Theoretical study on atmospheric chemistry of $\mathrm{CHF}_{2} \mathrm{CF}_{2} \mathrm{CH}_{2} \mathrm{OH}$ : Reaction with $\mathrm{OH}$ radicals, lifetime and global warming potentials. Computational and Theoretical Chem., v. 1119, p. 1 - 9, 2017.

CHRISTENSEN, L.K.; SEHESTED, J.; NIELSEN, O. J.; BILDE, M.; WALLINGTON, T. J.; GUSCHIN, A.; MOLINA, L. T.; MOLINA, M. J. Atmospheric Chemistry of HFE-7200 $\left(\mathrm{C}_{4} \mathrm{~F}_{9} \mathrm{OC}_{2} \mathrm{H}_{5}\right)$ : Reaction with $\mathrm{OH}$ Radicals and Fate of $\mathrm{C}_{4} \mathrm{~F}_{9} \mathrm{OCH}_{2} \mathrm{CH}_{2} \mathrm{O}(\bullet)$ and $\mathrm{C}_{4} \mathrm{~F}_{9} \mathrm{OCHO}(\bullet) \mathrm{CH}_{3}$ Radicals. J. Phys. Chem. A., v. 102, n. 25, p. 4839-4845, Feb./April. 1998.

DEKA, R.C.; MISHRA, B.K. Theoretical studies on kinetics, mechanism and thermochemistry of gas - phase reactions of $\mathrm{HFE}-449$ mec-f with $\mathrm{OH}$ radicals and $\mathrm{Cl}$ atom. J Molecular Graphics and Modeling, v. 53, p. 23-30, Jul. 2014.

DE CARVALHO, E. F. V.; ROBERTO-NETO, O. Effects of Multidimensional Tunneling in the Kinetics of Hydrogen Abstraction Reactions of $\mathrm{O}\left({ }^{3} \mathrm{P}\right)$ with $\mathrm{CH}_{3} \mathrm{OCHO}$. Journal of Computational Chemistry, p. 1-9, Jan./Feb. 2018.

ESPINOSA-GARCIA, J. Ab Initio and Variational Transition State Theory of the $\mathrm{CF}_{3} \mathrm{CF}_{2} \mathrm{OCH}_{3}+\mathrm{OH}$ Reaction Using Integrated Methods: Mechanism and Kinetics. J. Phys. Chem. A., v. 107, n. 10, p. 1618-1626, Jul./Dec. 2003.
GALANO, A.; ALVAREZ-IDABOY, J.R.; FRANCISCOMARQUEZ, M. Mechanism and Branching Ratio of Hydroxyl Ethers + $\mathrm{OH}$ Gas Phase Reactions: Relevance of H Bond Interactions. J. Phys. Chem. A., v. 144, n. 28, p. 7525-7536, April/May. 2010.

GARFIELD, E. Ozone-Layer Depletion: Its Consequences, the Causal Debate, and International Cooperation. Essays of an Information Scientist: Science Literacy, Policy, Evaluation and other Essays, v. 11, p. 39-49, 1988.

GOOD, D.A.; FRANCISCO, J.S.; JAIN, A.K.; WUEBBLES, D.J. Lifetime and global warming potentials for Dimethyl ether and for fluorinated ethers: $\mathrm{CH}_{3} \mathrm{OCH}_{3}$ (E143a), $\mathrm{CHF}_{2} \mathrm{OCHF}_{2}$ (E134), $\mathrm{CHF}_{2} \mathrm{OCF}_{3}$ (E125). Journal of Geophysical Research, v. 103, n. D21, p. 28186-28186, Nov. 1998.

GOUR, N.K.; MISHRA, B.K.; HUSSAINI, I.; DEKA, R.C. Theoretical Investigation on the kinetics and Thermochemistry of $\mathrm{H}$-atom abstraction reactions of 2chloroethyl methyl ether $\left(\mathrm{CH}_{3} \mathrm{OCH}_{2} \mathrm{CH}_{2} \mathrm{Cl}\right)$ with $\mathrm{OH}$ radical at 298 K. struct. Chem., p. 1 - 9, march/May. 2016.

GUO, Q.; ZHANG, N.; UCHIMARU, T.; CHEN, L.; QUAN, H.; MIZUKADO, J. Atmospheric chemistry of cyc- $\mathrm{CF}_{2} \mathrm{CF}_{2} \mathrm{CF}_{2} \mathrm{CH}=\mathrm{CH}-$ : Kinetics, products, and mechanism of gas-phase reaction with $\mathrm{OH}$ radicals, and atmospheric implications. Atmospheric Environment, v. 179, p. 69-76, Jan./Feb. 2018.

HASHEMI, S.R.; SAHEB, V. Theoretical Studies on the Mechanism and Kinetics of the Hydrogen Abstraction Reactions of threo- $\mathrm{CF}_{3} \mathrm{CHFCHFC}_{2} \mathrm{~F}_{5}$ and erthro$\mathrm{CF}_{3} \mathrm{CHFCHFC}_{2} \mathrm{~F}_{5}$ (HFC-43-10mee) by $\mathrm{OH}$ radicals. Computational \& Theoretical Chemistry, p. 1-28, May/Sept. 2017.

HURLEY, M. D.; WALLINGTON, T. J.; ANDERSEN, M. P. S.; ELLIS, D. A.; MARTIN, J. W.; MABURY, S. A. Atmospheric Chemistry of Fluorinated Alcohols: Reaction with $\mathrm{Cl}$ Atoms and $\mathrm{OH}$ Radicals and Atmospheric Lifetimes. J. Phys. Chem. A, v. 108, n. 11, p. 1973-1979, Oct./Jan. 2004.

LASZLO, B.; ROBERT, E.H.; MICHAEL, J.K.; ANDRZEJ,

W.M. Kinetic studies of the reactions of $\mathrm{BrO}$ and IO radicals. Journal of Geophysical Research, v. 102, n. D1, p. 1523-1532, Jan. 1997.

M A B U R Y, S. A.; YOUNG, C. J.; HURLEY, M. D.; WALLINGTON, T. J. Atmospheric Lifetime and Global Warming Potential of a Perfluoropolyether. Environ. Sci. Technol., v. 40, n. 7, p. 2242-2246, Oct./Jan. 2006.

MOLINA, J.M.; ROWLAND, F.S. Stratospheric sink for chlorofluoromethanes: chlorine atom-catalyzed destruction of ozone. Nature, v. 249, p. 810-812, Jun. 1974.

ORKIN, V. L.; VILLENAVE, E.; HUIE, R. E.; KURYLO, M. J. Atmospheric Lifetimes and Global Warming Potentials of Hydrofluoroethers: Reactivity toward OH, UV Spectra, and IR Absorption Cross Sections. J. Phys. Chem. A, v. 103, n. 48, p. 9770-9779, May/Sept. 1999.

PAPADIMITRIOU, V.C.; PAPANASTASIOU, D.K.; STEFANOPOULOS, V.G.; ZARAS, A.M.; LAZAROU, Y.G.; PAPAGIANNAKOPOULOS, P. Kinetics study of the Reactions of $\mathrm{Cl}$ Atoms with 
$\mathrm{CF}_{3} \mathrm{CH}_{2} \mathrm{CH}_{2} \mathrm{OH}, \quad \mathrm{CF}_{3} \mathrm{CF}_{2} \mathrm{CH}_{2} \mathrm{OH}, \quad \mathrm{CHF}_{2} \mathrm{CF}_{2} \mathrm{CH}_{2} \mathrm{OH}$ and $\mathrm{CF}_{3} \mathrm{CHFCF}_{2} \mathrm{CH}_{2} \mathrm{OH}$. J. Phys. Chem. A., v. 111, n. 45, p. $11608-11617$. Jun./Aug. 2007.

PHILIP, M. Advanced chemistry. Cambridge Low Price Edition, UK: 1996.

PRATHER, M.; SPIVAKOVSKY, C.M. Tropospheric OH and the Lifetimes of Hydrochlorofluorocarbons. Journal of Geophysical Research, v. 95, n. D11, 1872318729, Oct. 1990.

ROHRER, F.; BERRESHEIM, H. Strong correlation between levels of Tropospheric hydroxyl radical and solar ultraviolet radiation. Nature, v. 442, p. 184-187, Jul. 2006.

ROUSSEL, M. R. Transition State Theory (Chemistry and Biochemistry), $3^{\text {rd }}$ ed. University of Lethbridge, Canada: 2009.

ROWLAND, F.S. Stratospheric Ozone depletion. Phil. Trans. R. Soc. B, v. 361, p. 769-790. 1996.

ROWLEY, D. M.; FERRACCI, V. Kinetic studies of the BrO + $\mathrm{ClO}$ cross-reaction over the range $\mathrm{T}=246-314 \mathrm{~K}$. Phys. Chem., v. 16, p. 1182-1196, Aug./Oct. 2014.

SAKO, T.; SATO, M.; NAKAZAWA, N.; OOWA, M.; YASUMOTO, M.; ITO, H.; YAMASHITA, S. Critical Properties of Fluorinated Ethers. J. Chem. Eng. Data, v. 41, n. 4, p. 802-805, Dec./May. 1996.

SCHLAGER, H.; GREWE, V.; ROIGER, A. Chemical composition of the atmosphere. Springer, p. 17-35, 2012.

SIAKA, A.A.; UZAIRU, A.; IDRIS, A.; ABBA, H. Thermodynamics and Kinetics of Spiro - Heterocycle Formation Mechanism: Computational Study. Phys. Chem. Res., v. 5, n. 3, p. 439-446, Jan./Feb. 2017.

SPARTAN '14 v 114. Wave function, Inc., Irvine. 2013.

TRUHLAR, D. G.; GARRETT, B. C.; KLIPPENSTEIN, S. J. Current Status of Transition-State Theory. J. Phys. Chem., v. 100, n. 31, p.12771-12800, Dec./Feb. 1996.

WANG, Y-N.; CHEN, J.; LI, X.; WANG, B.; CAI, X.;
HUANG, L. Predicting rate constants of hydroxyl radical reactions with organic pollutants: Algorithm, Validation, applicability domain and mechanistic interpretation. Atmospheric Environment, v. 43, p. 1131-1135, Oct./Nov. 2009.

WHITE, C.W.; MARTELL, J.M. Hydrogen Abstraction from Fluorinated Ethyl Methyl Ether System by $\mathrm{OH}$ Radicals. Advances in Physical Chemistry, v. 2016, n. 3740278, p. 1-10, Jul./Nov. 2015.

WOFSY, S. C.; MCELROY, M. B.; YUNG, Y. L. The chemistry of atmospheric Bromine. Geophysical Research Letters, v. 2, n. 6, p. 215-218, Jun. 1975.

WORLD METEOROLOGICAL ORGANIZATION PROJECT - Report No. 52 Scientific Assessment of Ozone Depletion: Geneva Switzerland, ISBN: 9966-7319-6-2. 2010.

YANG, L.; LIU, J-Y.; WANG, L.; HE, H-Q.; WANG, Y.; LI, Z-S. Theoretical Study of the Reactions $\mathrm{CF}_{3} \mathrm{CH}_{2} \mathrm{OCHF}_{2}+\mathrm{OH} / \mathrm{Cl}$ and its Product Radicals and Parent Ether $\left(\mathrm{CH}_{3} \mathrm{CH}_{2} \mathrm{OCH}_{3}\right)$ with $\mathrm{OH}$. J Comput. Chem., v. 29, n. 4, p. 550-561, Jan./Jul. 2007.

YE, J-T.; BAI, F-Y.; PAN, X-M. Computational Study of Habstraction reactions from $\mathrm{CH}_{3} \mathrm{OCH}_{2} \mathrm{CH}_{2} \mathrm{Cl} / \mathrm{CH}_{3} \mathrm{CH}_{2} \mathrm{OCH}_{2} \mathrm{CH}_{2} \mathrm{Cl}$ by $\mathrm{Cl}$ atom and $\mathrm{OH}$ radical and fate of alkoxy radicals. Environ. Sci. Pollut. Res., v. 23, p. 23467-23484, may/Aug. 2016. 